\title{
An Examination Of The Country Liquidity Index To Predict A Country's Foreign Direct Investment
}

Roland J. Sparks, Johnson \& Wales University, USA

Nick Desai, Johnson C. Smith University, USA

Perumal Thirumurthy, Johnson C. Smith University, USA

\begin{abstract}
Foreign direct investment (FDI) is critical to the economic development of any nation regardless of its level of growth. There is a plethora of research on the determining factors of FDI, both economic and non-economic, but very little on the weighted influence of these factors. This research is an attempt to categorize and rank the major determinates of FDI. The conclusion reached by this research is that economic condition of a country is a major determining factor for FDI, but there are other competing factors, as well, that have major impact on FDI. Using the Country Liquidity Index (CLI) as a barometer, the FDI is regressed to develop a model to predict the potential FDI of a country. Results conclude that only $22.46 \%$ of a country's FDI is explained by economic factors leaving the remaining $77.54 \%$ unexplained. This research attempts to explain the unexplained factors and rank the countries as overinvested and underinvested. A review of the data for the over and underinvested countries indicates that political factors and third country influences may outweigh economic factors when it comes to FDI. The paper concludes with a ranking of 62 countries and their foreign direct investment potential along with their current over/under foreign direct investments.
\end{abstract}

Keywords: Country Liquidity Index; Foreign Direct Investment; FDI

\section{INTRODUCTION}

"For the first time since 2001, the U. S. knocked China out of first place in an annual survey of executives rating favorable places for foreign direct investment." (Hagerty, 2013)

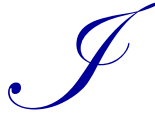

n 2011, foreign direct investment (FDI) in the top 100 countries totaled $\$ 1,713,523,303,561$ in U.S. dollars (World Bank Database, 2013). Previous literature indicates that a country's economic environment/conditions are the major determinant of foreign investment. However, further examination of the literature indicates no published work addresses how much a country's economic condition affects its ability to obtain foreign direct investments. This paper examines the previous literature on determinants of FDI, ranks the determinants by interest, develops a model that relates the economic factors of FDI to the Country Liquidity Index, and concludes by examining and ranking countries that are over or under invested.

The importance of this work is twofold. On the academic side, it is important to indentify the determinants of FDI and evaluate their weights in the investment decision. On the business side, this work identifies countries that have potential for additional FDI.

\section{LITERATURE REVIEW}

The literature in this field follows two major research tracks, determinants of foreign direct investment and specific country and industry case studies. This literature survey begins by indentifying, categorizing, and ranking 
the determinants of FDI. Next, individual case studies of various countries and industries are examined to complete the review of FDI determinants. The literature review concludes by indentifying gaps in the previous literature indicating further areas of research needed in this field.

Determinants for foreign direct investment can be categorized into five major areas: foreign country factors, political factors, home country factors, business investment cycles, and third country influences.

Foreign country factors accounted for the majority (54 journal articles) of the research. Within the specific foreign country factors, were sixteen major sub-factors identified in the literature that influences FDI. In order of most important (number of times mentioned) to least important the factors are:

1. Economic factors (37 journal articles): exchange rate (Rasheed, Sabir, Tahir, \& Farooq, 2012), interest rates (Uwubanmwen \& Ajao, 2012), available credit in country (Jurcau, Andreicovici, \& Matis, 2011), growth rates (Selelo \& Sikwila, 2012), inflation (Srinivasan, 2011), GDP (Choong \& Lam, 2010), unemployment rate and per capita income (Pearson, Nyonna, \& Kim, 2012).

2. Favorable government regulations (35 journal articles): trade openness (Azam \& Kukman, 2010), taxes (Leitao, 2010), low corruption (Mateev, 2009), strong property rights (Kawai, 2009), environmental regulations (Jimenez, Duran, \& De la Fuente, 2011) and stable government (Lin F., 2010).

3. Potential market size (17 journal articles): current target market within the country or area (Liu \& Pearson, 2010; Mhlanga, Blalock, \& Christy, 2010).

4. Well trained local workforce (11 journal articles): amount and availability of skilled labor in country (Dutta \& Osei-Yeboah, 2013; Liu, Daly, \& Varua, 2012).

5. Current relationship status (9 journal articles): already a current trading partner (Rienda, Claver, \& Quer, 2013), have existing FDI with home country (Cheng \& Chung, 2012) or have current established network linkages (Noh \& Yean, 2013).

6. Industry regional specialization (7 journal articles): industrial clusters of manufacturing (Hu, 2013) or specific technology production assets (Rienda, Claver, \& Quer, 2013).

7. Natural environmental resources (7 journal articles): current availability of natural resources for business purposes (Doytch, 2012; Ekanayake, Legerwood, \& Halkides, 2012).

8. Current infrastructure (6 journal articles): infrastructure is current or can support expansion (Nurudeen, Wafure, \& Auta, 2011; Hailu, 2010).

9. Low wage labor force (5 journal articles): amount of low wage workers available for production purposes (Hayakawa, Lee, \& Park, 2013; Leibrecht \& Scharler, 2009).

10. Geographical closeness (4 journal articles): countries that are in close physical presence to home country. Usually a border country (Mateev, 2009; Ragoussis, 2011).

11. Current economic development status (3 journal articles): used Dunning's Investment Development Path model to determine when to invest in a country (Molina-Martinez \& Alcaraz-Vargas, 2012).

12. Cultural Proximity (3 journal articles): to include similar cultures (Jimenez, Duran, \& De la Fuente, 2011) and languages (Sharma \& Bandara, 2010).

13. Protective labor rights for employees (2 journal articles): Egan (2012) argued countries with more protective labor laws are less risky and should attract FDI, while Leibrecht \& Scharler (2009) found no signficant relationship between FDI and labor laws.

14. Ownership, location, and internalization (2 journal articles): discusses the uses of Dunning's Eclectic Paradigm to determine FDI (Park, Lee, \& Hong, 2011).

15. Member of a trade organization like the WTO (2 journal articles): Aw \& Tan (2010) found that countries belonging to trade organizations had higher levels of FDI.

16. Low entry costs (1 journal article): countries with lower market entry costs had higher levels of FDI (Hayakawa, Lee, \& Park, 2013).

Political factors (23 journal articles) were the second most addressed category in FDI. The number one political reason governments wanted FDI was economic. Seventeen articles discussed either improving (Stankeviciene \& Lakstutiene, 2012; Molina-Martinez \& Alcaraz-Vargas, 2012), developing (Uwubanmwen \& Ajao, 2012) or transforming the economy (Sharma \& Bandara, 2010) through FDI. In addition, several articles specifically addressed how economic development improves political stability (Amal, Tomio, \& Raboch, 2010; 
Suliman \& Mollick, 2009), reduces poverty (Kalirajan \& Singh, 2010) and creates jobs (Hijzen, Jean, \& Mayer, 2011; Subramaniam \& Baharumshah, 2011).

Technology was the second most addressed political factor with three articles. Politicians wanted FDI to advance current technologies (Miyamoto, Lu, \& Shimazaki, 2011) and create technology spillover to other businesses and industries (Elmawazini, 2010; Fedderke \& Romm, 2006).

The remaining political reasons for supporting FDI found in the literature were using FDI to limit competition (Owusu-Antwi, 2012), secure foreign resources (Wang, 2012) and exporting pollution or trash (Hall, 2009; Spatareanu, 2007).

Home country factors for foreign direct investment (5 journal articles) include home government support for FDI (Cheng \& Chung, 2012), companies seeking specific knowledge they did not posses (Chidlow, Salciuviene, \& Young, 2009), a follow the leader mentality (Buch, Kleinert, Lipponer, \& Toubal, 2005), high local wages (Hayakawa, Lee, \& Park, 2013) and home country tax rates (Wijewerra \& Mounter, 2007).

Business investment cycles (2 journal articles) addressed how FDI ebbs and flows with current economic (Pradhan \& Saha, 2011) and business cycles (Cavallari \& D'Addona, 2013). Cavallari (2013) showed how the current business cycle affected the FDI in the United States while Pradhan (2011) found evidence that FDI increased in India when there was an economic expansion driving increased world consumption.

Third country influences (Baltagi, Egger, \& Pfafermayr, 2007) examined how actions of another country influenced FDI between two other countries. They looked at how the United States could affect the FDI between two other countries through a complex integration strategies model of multinational companies.

Summarizing the determinants of the foreign direct investment research track indicates that economics appears to be the number one examined reason for FDI. Both foreign country and political categories rated economics as the key factor in FDI. However, no research ever examined the weight the economic factors contribute in the FDI process.

\section{Country and Industry Case Studies}

Next, the literature examines the second research track of case studies on FDI. In specific, what are the breadth and depth of current research with respect to countries and industries?

\section{Country Case Studies}

The number one country examined in case studies is China (10 journal articles) (Liu, Daly, \& Varua, 2012; Mucchielli \& Yu, 2011). Followed by Malaysia (6 journal articles) (Noh \& Yean, 2013; Athukorala \& Wagle, 2011), Pakistan (5 journal articles) (Zafar, 2013; Rasheed, Sabir, Tahir, \& Farooq, 2012), India (4 journal articles) (Syddl \& Sreenivasa, 2011; Vivoda, 2011), Korea (3 journal articles) (Ha, Lee, Kim, \& Rhee, 2009; Kim \& Rhe, 2009), Nigeria (3 journal articles) (Uwubanmwen \& Ajao, 2012; Olufemi Oke, Ezike, \& Ojogbo, 2021), Africa (3 journal articles) (Owusu-Antwi, 2012; Mhlanga, Blalock, \& Christy, 2010), Egypt, Jordan, Yemen (3 journal articles) (Al Abbadi, 2010; Bakir \& Alfawwaz, 2009), and the United Kingdom (2 journal articles) (Dimitropoulou, McCann, \& Burke, 2013; Fallon \& Cook, 2010). The following countries only had one case study article written: Norway (Rezza, 2013), Taiwan (Hayakawa, Lee, \& Park, 2013), Mozambique (Tembe \& Xu, 2012), Botswana (Selelo \& Sikwila, 2012), Mexico (Molina-Martinez \& Alcaraz-Vargas, 2012), Russia (Anil, Armutlulu, Canel, \& Porterfield, 2011), Canada (Leitao, 2010), Turkey (Zeren \& Ergun, 2010), Spain (Rodriguez \& Bustillo, 2010), Australia (Sharma \& Bandara, 2010), Czech \& Slovak Republic (Venkataramany \& Miklovich, 2010), Indonesia (Azam \& Kukman, 2010), Albania (Bitzenis \& Szamosi, 2009), Cambodia (Cuyvers, Soeng, Plasmans, \& Van Den Bulcke, 2011), and Poland (Chidlow, Salciuviene, \& Young, 2009). In addition to specific country studies, the literature presented various regional studies to include Europe (4 journal articles) (Jimenez, Duran, \& De la Fuente, 2011; Artige \& Nicolini, 2010), and single articles on Eastern Europe (Doytch, 2012), the Baltic (Stankeviciene \& Lakstutiene, 2012), Central Asia (Doytch, 2012), South Asia (Bhavan, Xu, \& Zhong, 2011), and Latin America (Amal, Tomio, \& Raboch, 2010). 
Although most case studies were country specific one case study examined in-country differences. $\mathrm{Hu}$ (2013) discovered that FDI within the country of China varied by region indicating that for large countries the country study approaches may not be reliable.

\section{Industry Case Studies}

In addition to country case studies, the literature examined industry case studies addressing FDI in manufacturing (5 journal articles) (Rezza, 2013; Lin F., 2010), service sector (4 journal articles) (Noh \& Yean, 2013; Ramasamy \& Yeung, 2010), and pharmaceuticals (2 journal articles) (Syddl \& Sreenivasa, 2011; Jiang, 2006). Single journal articles examined FDI in banking (Gulamhussen, 2012), Agricultural (Doytch, 2012), information technology and telecommunications (Syddl \& Sreenivasa, 2011), mining (Vivoda, 2011), and real estate (Rodriguez \& Bustillo, 2010).

The literature concerning the determinants of FDI included 29 countries, 4 world regions, both manufacturing and service sectors, and industry specific businesses. Yet no journal article addresses the weighted influence that a country's economic condition has on foreign direct investment compared with the other 15 major determinants of FDI. This leaves a gap in current literature that this research will explore.

\section{METHODOLOGY}

To determine the impact of a country's economic factors to the foreign direct investment it receives requires a measure of a country's current economic condition. The issue is that there is no one agreed upon measure to determine this. However, the Country Liquidity Index (Sparks, Desai, \& Thirumurthy, 2012) developed a measure of how well a country's government was managing its available cash. The higher the index number, the more attractive the country is to foreign investment. Countries with a negative Liquidity Index carry too much debt and would not be suitable for FDI. The Country Liquidity Index (CLI) currently ranks 63 of the world's top countries and is based primarily on the economic criteria that businesses can use to identify FDI opportunities.

Using the Country Liquidity Index as a proxy for the country's economic factors that affect FDI, a relationship between the CLI and FDI would indicate the weight that economic factors have in influencing the foreign direct investment amounts for a country. Various regression techniques (linear, exponential, log) were examined to find the best regression fit for the data. Foreign direct investment data from the World Bank was available for 62 of the CLI countries. World Bank's 2011 data, the latest complete set, was used for this study.

Based on the SPSS results of the various regression models, the linear regression model was chosen as the best fit model by both the R-Squared and $\mathrm{p}$ values. This gives the regression formula for a country's FDI as:

$\mathrm{FDI}=\mathrm{b}_{0}+\mathrm{b}_{1}(\mathrm{CLI})$

where:

FDI - Foreign direct investment in US dollars

CLI - Country Liquidity Index

\section{RESULTS AND ANALYSIS}

The results of the regression revealed an FDI prediction formula of:

$\mathrm{FDI}=58,074,771,998+4,301,407,944(\mathrm{CLI})$

The p-value for the CLI coefficient was 0.000059 indicating a statistically significant relationship. Adjusted R-Squared for the model was 0.2246 , indicating that $22.46 \%$ of the reason for a country's foreign direct investment is explained by economic factors. Based on the regression formula, a table of countries with their predicted 2011, FDI amounts was generated. (Appendix A) The table is sorted by country from the highest predicted FDI to the lowest predicted FDI, and by the country that is most overinvested to the country that is most underinvested. 
The significant result of this study is that although economic factors are the number one studied factor in foreign direct investment, they do not account for a large percentage of the reason a country obtains FDI. In fact, $77.54 \%$ of the reasons for FDI still have yet to be addressed. The literature review presented 16 foreign country factors, 5 political factors, 5 home country factors, business and economic cycle factors, and third country intervention factors that still need to be measured and related to FDI to get a complete picture. Further, analysis of the countries that are over/under invested may lead to new insights.

The top 10 over invested countries are: United States $(\$ 173,018,737,004)$, China $(\$ 167,898,324,238)$, Belgium $(\$ 65,481,706,161)$, Brazil $(\$ 57,504,651,489)$, Russia $(\$ 36,131,012,707)$, India $(\$ 25,951,091,584)$, Egypt $(\$ 20,518,304,797)$, Italy $(\$ 19,623,061,601)$, Greece $(\$ 18,614,780,944)$, and Singapore $(\$ 18,406,963,600)$. Examining the first two, United States and China and comparing them to the 29 reasons in the literature would indicate 'follow the leader' mentality, favorable government regulations and potential market size for strong FDI. These three factors may also be true for India. Countries like Brazil, Russia, Egypt, Italy, and Greece with weaker or failing economies are attracting far too much foreign investment then their economic numbers support. This may indicate third country influences are politically supporting these countries. Therefore, political concerns may have greater weight then economic factors in FDI.

The top 10 underinvested countries are: Finland $(\$ 50,885,848,323)$, New Zealand $(\$ 49,746,484,373)$, Switzerland $(\$ 48,425,610,794)$, Sweden $(\$ 47,144,849,022)$, Japan $(\$ 43,827,557,674)$, Estonia $(\$ 40,612,653,929)$, Luxembourg $(\$ 35,864,212,815)$, Norway $(\$ 34,419,827,018)$, Denmark $(\$ 33,021,322,379)$, and the Netherlands $(\$ 32,762,075,278)$. The top 10 underinvested countries all have developed infrastructure, stable governments, good economies, fairly open trade regulations, good potential market sizes, well trained workforces, and are members of various trade organizations. Yet they are not receiving the amount of FDI they should, based on their economies. This indicates that political factors or third country influences steering money away from these countries may be a heavily weighted factor in FDI.

The data results in the study were fairly consistent. However, there is concern about the data points for the United States and China. Both were on the edge of being outliers for the data and are clearly well above the projected regression line. Also it seems that China and the United States are the exceptions from other countries, in that noneconomic factors favor more FDI in these two countries compared to others. This supports the theory that political influences or 'follow the leader' mentality may be heavily weighed factors in FDI.

\section{CONCLUSION}

This paper examined the factors that influenced FDI in countries. Based on the literature review, the economic factors seemed to be the number one discussed reason for current FDI levels. However, analysis of economic factors found that only $22.46 \%$ of FDI was influenced by a countries economic status. This leaves the remaining $77.54 \%$ of FDI factors unexplained. A review of over and under invested countries indicates that political factors and third country influence may weigh more heavily on FDI than economic factors. Further research in this area is needed to better understand the factors that affect FDI and how much each factor influences the investment decision.

\section{AUTHOR INFORMATION}

Roland Sparks, DBA, PE, CPM, is an associate professor of business at Johnson and Wales University. His research areas are diverse and include the areas of international business, business education, and technology. Previous publications include predicting business expansion in foreign markets, development of the micro-survey concept, predicting reward error in surveys, uses of technology in business and education, developing effective methods for internet surveys, ecommerce and the business education. Sparks spent 15 years as an engineer and project manager before becoming an academic. He holds a BS in Physics, MBA, MS and DBA in International Business. Roland J. Sparks, DBA, Associate Professor Business, College of Business, Johnson \& Wales University, 801 West Trade Street, Charlotte, NC 28202 USA. E-mail: roland.sparks@jwu.edu (Corresponding author) 
N. V. Desai, Ph.D., CPA, is a professor of economics at Johnson C. Smith University in Charlotte NC. He has diversified experience in the industry as well as in academics. He has occupied positions such as head of the department of business and economics and controller of the University. Dr. Desai was instrumental in guiding ACBSP accreditation for Johnson C. Smith University's Business program. He has presented and published papers internationally and nationally. He has to his credit many fellowships like Japanese Peace Foundation Fellowships, Mellon Foundation Fellowships, and Salzburg Global Seminar Fellowships. He was a Scholar in Residence at New York University. Dr. Desai is a Board member of academic and non academic institutions. Nick Desai, PhD, Professor of Economics, School of Business and Economics, Johnson C. Smith University, 100 Beatties Ford Road, Charlotte, NC 28202 USA. E-mail: ndesai@jcsu.edu

Perumal Thirumurthy, MBA, MA, CPA, received his undergraduate and Master degree in Economics from Annamalai University, India and earned his M.B.A. from Pfeiffer University, Charlotte, N.C. He joined the ranks of the J. C. Smith University as a faculty in January 1985. He has presented papers in both national and international business conferences. He co-authored the award winning paper "Measuring e-commerce satisfaction: Reward error and emergence of Micro-Surveys" which was presented at the 2006 International Association for the Development of the Information Society (IADIS) Conference in Barcelona, Spain. He is a member of the American Institute of Certified Public Accountants and North Carolina Association of Public Accountants. Perumal Thirumurthy, MBA, MA, CPA, Assistant Professor of Accounting, School of Business and Economics, Johnson C. Smith University, 100 Beatties Ford Road, Charlotte, NC 28202 USA. E-mail: pthirumurthy@jcsu.edu

\section{REFERENCES}

1. Al Abbadi, A. F. (2009, Dec). Diagnosis of the current situation of foreign investment in some Arab economies. International Management Review, 5(2), 55-64.

2. Al Abbadi, A. F. (2010, Nov). Diagnosis of the current situation of foreign investment in some Arab economies. Journal of Economics, Finance \& Administrative Sciences, 26, 23-32.

3. Amal, M., Tomio, B. T., \& Raboch, H. (2010). Determinants of foreign direct investment in Latin America. GCG: Revista de Globalizacion, Competitvidad \& Gobernabilidad, 4(3), 116-133.

4. Anil, I., Armutlulu, I., Canel, C., \& Porterfield, R. (2011, Nov). The determinants of Turkish outward foreign direct investment. Modern Economy, 2(5), 717-728.

5. Artige, L., \& Nicolini, R. (2010, Feb). Market potential, productivity and foreign direct investment: Some evidence from three case studies. European Planning Studies, 18(2), 147-168.

6. Asheghian, P. (2009). Determinants of economic growth in Japan: The role of foreign direct investment. Global Economy Journal, 9(3), 1-9.

7. Athukorala, P., \& Wagle, S. (2011, Aug). Foreign direct investment in Southeast Asia: Is Malaysia falling behind. ASEAN Economic Bulletin, 28(2), 115-133.

8. Aw, T., \& Tan, T. (2010, Jan). The determinants of inward foreign direct investment: The case of Malaysia. International Journal of Business \& Society, 11(1), 59-76.

9. Awan, M. Z., Zaman, K., \& Khan, B. (2010). Determinants of foreign direct investment in services sector of Pakistan: An econometric approach. IBA Business Review, 5(2), 167-180.

10. Azam, J., \& Kukman, L. (2010, Jan-Jun). Determinants of foreign direct investment in India, Indonesia and Pakistan: A quantitative approach. Journal of Managerial Sciences, 4(1), 31-44.

11. Azemar, C., Julia, D., Desbordes, R., \& Wooton, I. (2012, Nov). Market familiarity and the location of south and north MNEs. Economics \& Politics, 24(3), 307-345.

12. Bakir, A., \& Alfawwaz, T. (2009, Dec). Determinants of foreign direct investment in Jordan. International Management Review, 5(2), 65-72.

13. Baltagi, B., Egger, P., \& Pfafermayr, M. (2007, Sep). Estimating models of complex FDI: Are there thirdcountry effects. Journal of Econometrics, 140(1), 260-281.

14. Bellak, C., Leibrecht, M., \& Damijan, J. P. (2009, Feb). Infrastructure endowment and corporate income taxes as determinants of foreign direct investment in Central and Eastern European Countries. World Economy, 32(2), 267-290.

15. Bhavan, T., Xu, C., \& Zhong, C. (2011, Jan). Determinants and growth effect of FDI in South Asian economies: Evidence from a panel data analyisis. International Business Research, 4(1), 43-50. 
16. Bitzenis, A., \& Szamosi, L. T. (2009, Jul-Dec). Entry modes and the determinants of foreign direct investment in a european union accession country: The case of Albania. Journal of East-West Business, 15(3/4), 189-209.

17. Buch, C. M., Kleinert, J., Lipponer, A., \& Toubal, F. (2005, Jan). Determinants and effects of foreign direct investment: Evidence from German firm-level data. Economic Policy, 20(41), 52-110.

18. Cavallari, L., \& D'Addona, S. (2013, Jul). Business cycle determinants of US foreign direct investments. Applied Economics Letters, 20(10), 966-970.

19. Cheng, Y., \& Chung, L. (2012, Mar). Investment. Journal of Contemporary Management Research, 6(1), $1-14$.

20. Chidlow, A., Salciuviene, L., \& Young, S. (2009, Apr). Regional determinants of inward FDI distribution in Poland. International Business Review, 18(2), 119-133.

21. Choong, C., \& Lam, S. (2010). The determinants of foreign direct investment in Malaysia: A revisit. Global Economic Review, 39(2), 175-195.

22. Cuyvers, L., Soeng, R., Plasmans, J., \& Van Den Bulcke, D. (2011, Jun). Determinants of foreign direct investment in Cambodia. Journal of Asian Economies, 22(3), 222-234.

23. Dimitropoulou, D., McCann, P., \& Burke, S. P. (2013, Sep). The determinants of the location of foreign direct investment in UK regions. Applied Economics, 45(27), 3853-3862.

24. Doytch, N. E. (2012, Nov). Institutional determinants of sectoral FDI in Eastern European and Central Asian countries: The role of investment climate and democracy. Emerging Markets Finance \& Trade, 48, 14-32.

25. Dutta, N., \& Osei-Yeboah, K. (2013, Mar). A new dimension to the relationship between foreign direct investment and human capital: The role of political and civil rights. Journal of International Development, 25(2), 160-179.

26. Egan, P. J. (2012, Aug). Is worker repression risky? Foreign direct investment, labour rights and assessments of risk in developing countries. Review of International Political Economy, 19(3), 415-447.

27. Ekanayake, E. M., Legerwood, J. R., \& Halkides, M. (2012, Jun). Determinants of United States outbound foreign direct investment in Latin America and Caribbean: A panel data analysis. Global Conference on Business \& Finance Proceedings, 7(2), 464-464.

28. Elmawazini, K. (2010, Aug). Foreign direct investment, technology spillovers, and host country spending on R \& D. International Advances in Economic Research, 16(3), 325-325.

29. Fallon, G., \& Cook, M. (2010, Apr). Exploring the regional distribution of inbound foreign direct investment in the UK in theory and practice: Evidence from a five-region study. Regional Studies, 44(3), 337-353.

30. Fedderke, J. W., \& Romm, A. T. (2006, Sep). Growth impact and determinants of foreign direct investment into South Africa, 1956-2003. Economic Modelling, 23(5), 738-760.

31. Gulamhussen, M. A. (2012, Nov/Dec). FDI in investment banking. Thunderbird International Business Review, 54(6), 921-934.

32. Ha, J. W., Lee, J. Y., Kim, C. W., \& Rhee, B. (2009). What kind of location-specific advantages have US firms been looking for from foreign direct investment in South Korea? Journal of International Finance \& Economics, 9(4), 104-109.

33. Hagerty, J. R. (2013, Jun 26). U. S. overtakes China - Nation ranks first in survey on foreign-investment climate. The Wall Street Journal, B5.

34. Hailu, Z. A. (2010, May). Demand side factors affecting the inflow of foreign direct investment to African countries: Does capital market matter? International Journal of Business \& Management, 5(5), 104-116.

35. Hall, D. (2009, May). Pollution export as state and corporate strategy: Japan in the 1970s. Review of International Political Economy, 16(2), 260-283.

36. Hayakawa, K., Lee, H., \& Park, D. (2013, Jun). The role of home and host country characteristics in FDI: Firm-level evidence from Japan, Korea and Taiwan. Global Economic Review, 42(2), 99-112.

37. Hijzen, A., Jean, S., \& Mayer, T. (2011, Sep). The effects at home of initiating production abroad: Evidence from matched French firms. Review of the World Economics, 147(3), 457-483.

38. Hu, Y. (2013, Apr). Research on the determinants of foreign direct investment inflows of Gansu Province China. International Journal of Financial Research, 4(2), 148-153.

39. Jiang, F. (2006, Dec). The determinants of the effectiveness of foreign direct investment in China: An empirical study of joint and sole ventures. International Journal of Management, 23(4), 891-908. 
40. Jimenez, A., Duran, J. J., \& De la Fuente, J. M. (2011, May). Political risk as a determinant of investment by Spanish multinational firms in Europe. Applied Economics Letters, 18(8), 789-793.

41. Jurcau, A., Andreicovici, I. I., \& Matis, D. (2011). The macroeconomic determinants of Romanian crossborder mergers and acquisitions. International Journal of Business Research, 11(2), 224-229.

42. Kalirajan, K., \& Singh, K. (2010, May). Economic liberalisation strategies and poverty reduction across Indian states. Asian-Pacific Economic Literature, 24(1), 26-42.

43. Kawai, N. (2009). Location strategies of foreign investors in China; Evidence from Japanese manufacturing multinationals. Global Economic Review, 38(2), 117-141.

44. Kim, J. M., \& Rhe, D. K. (2009). Trends and determinants of South Korean outward foreign direct investment. Copenhagen Journal of Asian Studies, 27(1), 126-154.

45. Kogid, M., Mulok, D., Beatrice, L. F., \& Mansur, K. (2010, Sep). Determinant factors of economic growth in Malaysia: Multivariate cointegration and causality analysis. Journal of Economics, Finance \& Administrative Sciences, 24, 123-137.

46. Leibrecht, M., \& Scharler, J. (2009, Jul). How important is employment protection legislation for foreign direct investment flows in Central and Eastern European countries? Economics of Transition, 17(2), 275295.

47. Leitao, N. C. (2010, Nov). Foreign direct investment: The Canadian experience. International Journal of Economics \& Finance, 2(4), 82-88.

48. Lin, F. (2010, May). The determinants of foreign direct investment in China: The case of Taiwanese firms in the IT industry. Journal of Business Research, 63(5), 479-485.

49. Lin, M., \& Kwan, Y. K. (2011, Jul). Sectoral location of FDI in China. World Economy, 34(7), 1181-1198.

50. Liu, K., Daly, K., \& Varua, M. E. (2012, Dec). Regional determinants of foreign direct investment in manufacturing industry. International Journal of Economics \& Finance, 4(12), 178-192.

51. Liu, Y., \& Pearson, C. (2010). An empirical study of the determinants of foreign investment in China: A Western Australian perspective. Journal of Asia-Pacific Business, 11(2), 99-120.

52. Mateev, M. (2009). Determinants of foreign direct investment in Central and Southeastern Europe: New empirical tests. Oxford Journal, 8(1), 133-149.

53. Mhlanga, N., Blalock, G., \& Christy, R. (2010, May). Understanding foreign direct investment in the Southern African development community: An analysis based on project-level data. Agricultural Economics, 41(3/4), 337-347.

54. Miyamoto, M., Lu, X., \& Shimazaki, Y. (2011, Sep). Patterns and determinants of China's outward foreign direct investment in 2008. Journal of Accounting \& Finance, 11(3), 113-124.

55. Mohamed, S. E., \& Sidiropoulos, M. G. (2010, Jun). Another look at the determinants of foreign direct investment in MENA countries: An empirical investigation. Journal of Economic Development, 35(2), 7596.

56. Molina-Martinez, R., \& Alcaraz-Vargas, J. J. (2012). The competition of Mexican States: Attracting foreign direct investment. Advances in Competitiveness Research, 20(3/4), 59-74.

57. Moosa, I. A. (2009, Oct). The determinants of foreign direct investment in MENA countries: An extreme bounds analysis. Applied Economics Letters, 16(15), 1559-1563.

58. Mucchielli, J.-L., \& Yu, P. (2011, Aug). Do "newly oligopolistic reaction" and host technology resources matter for MNCs location? - A Study in China's technology industries. Technology \& Investment, 2(3), 171-183.

59. Noh, N., \& Yean, T. S. (2013). Foreign firms' perspectives on investing in the services sector in Malaysia: An exploratory study. Annual International Conference on Qualitative \& Quantitative Economics Research (pp. 104-113). Phuket, Thailand: Global Science and Technology Forum.

60. Nurudeen, A., Wafure, O. G., \& Auta, E. M. (2011, Aug). Determinant of foreign direct investment: The case of Nigeria. IUP Journal of Monetary Economics, 9(3), 50-67.

61. Olufemi Oke, B., Ezike, J. E., \& Ojogbo, S. O. (2021, Apr). Locational determinants of foreign direct investments in Nigeria. International Business Research, 5(4), 103-111.

62. Owusu-Antwi, G. (2012, Jul). Determinant of foreign direct investment: Is it a better prescription for economic growth in Africa? International Business \& Economics Research Journal, 11(7), 757-770.

63. Park, Y.-R., Lee, J. Y., \& Hong, S. (2011, Mar). Location decision of Korean manufacturing FDI: A comparison between Korean Chaebols and Non-Chaebols. Global Economic Review, 40(1), 123-138. 
64. Pearson, D., Nyonna, D., \& Kim, K.-J. (2012, Oct). The Relationship between economic freedom, state growth and foreign direct investment. International Journal of Economics \& Finance, 4(10), 140-146.

65. Pradhan, J. P. (2004, Dec). The determinants of outward foreign direct investment: A firm level analysis of Indian manufacturing. Oxford Development Studies, 32(4), 619-639.

66. Pradhan, R. P., \& Saha, D. (2011, Aug). Determinants of foreign direct investment in SAARC countries: An investigation using panel VAR model. Information Management \& Business Review, 3(2), 117-126.

67. Ragoussis, A. (2011, Sep). The investment development path of space. Review of World Economics, 147(3), 527-541.

68. Ramasamy, B., \& Yeung, M. (2010, Apr). The determinants of foreign direct investment in services. World Economy, 33(4), 573-596.

69. Rasheed, M. K., Sabir, H. M., Tahir, S. H., \& Farooq, M. U. (2012, Dec). Determinants of foreign direct investment in Pakistan over the period 1975-2011. Interdisciplinary Journal of Contemporary Research in Business, 4(8), 202-210.

70. Rehman, A., \& Raza, A. (2011, Jan). Determinants of foreign direct investment and its impact on GDP growth in Pakistan. Interdisciplinary Journal of Contemporary Research in Business, 2(9), 198-205.

71. Rezza, A. A. (2013, Jun). FDI and pollution havens: Evidence from the Norwegian manufacturing sector. Ecological Economics, 90, 140-149.

72. Rienda, L., Claver, E., \& Quer, D. (2013, Feb). The internationalisation of Indian multinationals: Determinants of expansion through acquisitions. Journal of the Asia Pacific Economy, 18(1), 115-132.

73. Rodriguez, C., \& Bustillo, R. (2010, Oct). Modelling foreign real estate investment: The Spanish case. Journal of Real Estate Finance \& Economics, 42(3), 354-367.

74. Selelo, S. E., \& Sikwila, M. N. (2012, Jul). Determinants of fixed foreign direct investment in Botswana. Journal of Economics \& Behavioral Studies, 4(7), 414-422.

75. Sharma, K., \& Bandara, Y. (2010, Sep). Trends, patterns and determinants of Australian foreign direct investment. Journal of Economic Issues, 44(3), 661-676.

76. Sharma, K., Nayagam, J., \& Chung, H. H. (2012, Spring). Determinants of foreign direct investment in Malaysia: New evidence from cointegration and error correction model. Journal of Developing Areas, 46(1), 71-89.

77. Sparks, R. J., Desai, N., \& Thirumurthy, P. (2012, Dec). Diverging Government debt in a converging business world. An examination of the government liquidity index. The Exchange, 1(1), 17-34.

78. Sparks, R. J., Desai, N., \& Thirumurthy, P. (2013, Spring). Is China becoming the new world creditor? A study on global financial stability and liquidity of governments. The International Journal of the Academic Business World, 7(1), 29-38.

79. Spatareanu, M. (2007, Jun). Searching for pollution havens: The impact of environmental regulations on foreign direct investment. Journal of Environment \& Development, 16(2), 161-182.

80. Srinivasan, P. (2011, Aug). Determinants of foreign direct investment in SAARC nations: An econometric investigation. IUP Journal of Managerial Economics, 9(3), 26-42.

81. Stankeviciene, J., \& Lakstutiene, A. (2012). The research on determinants of foreign direct investment raising and their change trends in the Baltic countries. Management Theory \& Studies for Rural Business \& Infrastructure Development, 33(4), 72-83.

82. Stoian, C. (2013, Jun). Extending Dunning's investment development path: The role of home country institutional determinants in explaining outward foreign direct investment. International Business Review, 22(3), 615-637.

83. Subramaniam, T., \& Baharumshah, A. Z. (2011, Aug). Unemployment and speed of adjustment in the ASEAN-3 economies: A cointegration analysis. Singapore Economic Review, 56(3), 327-347.

84. Suliman, A. H., \& Mollick, A. V. (2009, Mar). Human capital development, war and foreign direct investment in sub-Saharan Africa. Oxford Development Studies, 37(1), 47-61.

85. Syddl, K. S., \& Sreenivasa, M. (2011, Dec). Trends of FDI inflows in India in the post-liberalization period - A study with special reference to pharmaceutical sector. Advances in Management, 4(12), 46-52.

86. Tembe, P., \& Xu, K. (2012, Oct). Attracting foreign direct investment in developing countries: Determinants and policies - A comparative study between Mozambique and China. International Journal of Financial Research, 3(4), 69-81.

87. Todo, Y. (2011, Mar). Quantitative evaluation of the determinants of export and FDI: Firm-level evidence from Japan. World Economy, 34(3), 355-381. 
88. Uwubanmwen, A. E., \& Ajao, M. G. (2012, Dec). The determinants and impacts of foreign direct investment in Nigeria. International Journal of Business \& Management, 7(24), 67-77.

89. Vadlamannati, K. C., Tamazian, A., \& Irala, L. R. (2009, Aug). Determinants of foreign direct investment and volatility in South East Asian economies. Journal of the Asia Pacific Economy, 14(3), 246-261.

90. Venkataramany, S., \& Miklovich, P. A. (2010, May). The impact of liberalization on foreign direct investment in the Slovak Republic. International Business \& Economics Research Journal, 9(5), 71-77.

91. Vivoda, V. (2011, Mar). Asia: A comparison between China and India. Resources Policy, 36(1), 49-59.

92. Wang, M. (2012, Jan). Empirical study on african energy resources and China's Outflow foreign direct investment. Journal of International Business Research, 11(1), 19-27.

93. Wijewerra, A., \& Mounter, S. (2007). AVAR analysis of the impacts of company tax rates on foreign direct investment and other macro-economic variables in Australia. Global Economic Review, 36(2), 137-145.

94. Wijewerra, A., Dollery, B., \& Clark, D. (2007, Jan 20). Corporate tax rates and foreign direct investment in the United States. Applied Economics, 39(1), 109-117.

95. World Bank. (2013). Foreign direct investment, net inflows (BoP, Current US\$). Retrieved from http://data.worldbank.org/indicator/BX.KLT.DINV.CD.WD

96. Yuan, L., \& Pangarkar, N. (2010). Inertia Versus mimicry in location choices by Chinese multinationals. International Marketing Review, 27(3), 295-315.

97. Zafar, M. (2013, Jan). Determinants of stock market performance in Pakistan. Journal of Contemporary Research in Business, 4(9), 1017-1026.

98. Zeren, F., \& Ergun, S. (2010). The determinants of foreign direct investment flows in EU: Dynamic panel data analysis. Business \& Economics Research Analysis, 1(4), 67-83.

99. Zhang, X., \& Daly, K. (2011, Dec). The determinants of China's outward foreign direct investment. Emerging Markets Review, 12(4), 389-398.

100. Zheng, P. (2011, Jun). The determinants of disparities in inward FDI Flows to the three macro-regions of China. Post-Communist Economies, 23(2), 257-270. 


\begin{tabular}{|c|c|c|c|c|c|}
\hline \multicolumn{6}{|c|}{ APPENDIX A: FDI Over and Under Estimates by Country (\$US) } \\
\hline \multicolumn{3}{|c|}{ Sorted by Predicted FDI } & \multicolumn{3}{|c|}{ Sorted by Over/Under Invested } \\
\hline Country & $\begin{array}{c}\text { Predicted } \\
\text { Foreign Direct } \\
\text { Investment } 2011\end{array}$ & $\begin{array}{c}\text { Over Invested } \\
\text { (Under Invested) }\end{array}$ & Country & $\begin{array}{c}\text { Predicted } \\
\text { Foreign Direct } \\
\text { Investment } 2011\end{array}$ & $\begin{array}{c}\text { Over Invested } \\
\text { (Under Invested) }\end{array}$ \\
\hline United States & $84,509,262,996$ & $173,018,737,004$ & United States & $84,509,262,996$ & $173,018,737,004$ \\
\hline Germany & $59,238,448,312$ & $(20,171,679,096)$ & China & $52,244,961,192$ & $167,898,324,238$ \\
\hline Switzerland & $58,502,735,497$ & $(48,425,610,794)$ & Belgium & $36,517,852,369$ & $65,481,706,161$ \\
\hline Australia & $54,966,074,872$ & $12,672,372,288$ & Brazil & $14,034,005,920$ & $57,504,651,489$ \\
\hline Luxembourg & $54,229,716,846$ & $(35,864,212,815)$ & Russia & $16,747,463,093$ & $36,131,012,707$ \\
\hline New Zealand & $54,031,593,996$ & $(49,746,484,373)$ & India & $6,238,908,416$ & $25,951,091,584$ \\
\hline China & $52,244,961,192$ & $167,898,324,238$ & Egypt & $(21,001,004,797)$ & $20,518,304,797$ \\
\hline Sweden & $50,198,738,419$ & $(47,144,849,022)$ & Italy & $8,379,461,065$ & $19,623,061,601$ \\
\hline Netherlands & $46,647,840,133$ & $(32,762,075,278)$ & Greece & $(17,522,800,305)$ & $18,614,780,944$ \\
\hline Denmark & $46,126,896,617$ & $(33,021,322,379)$ & Singapore & $45,596,490,004$ & $18,406,963,600$ \\
\hline United Kingdom & $45,696,196,640$ & $(9,452,398,812)$ & Mexico & $4,464,405,583$ & $16,358,892,270$ \\
\hline Singapore & $45,596,490,004$ & $18,406,963,600$ & Venezuela & $(9,410,732,050)$ & $14,636,732,050$ \\
\hline Finland & $45,127,851,608$ & $(50,885,848,323)$ & Australia & $54,966,074,872$ & $12,672,372,288$ \\
\hline Canada & $44,219,179,180$ & $(4,709,063,328)$ & Colombia & $2,937,878,918$ & $10,666,821,827$ \\
\hline Japan & $43,906,638,879$ & $(43,827,557,674)$ & Thailand & $1,051,109,337$ & $6,728,898,492$ \\
\hline Austria & $43,080,037,314$ & $(27,346,111,105)$ & Indonesia & $11,559,491,958$ & $6,600,041,773$ \\
\hline Norway & $41,700,446,744$ & $(34,419,827,018)$ & France & $39,103,600,741$ & $6,105,282,271$ \\
\hline Estonia & $41,048,740,427$ & $(40,612,653,929)$ & Morocco & $(3,564,731,527)$ & $6,086,096,172$ \\
\hline France & $39,103,600,741$ & $6,105,282,271$ & Pakistan & $(4,360,578,025)$ & $5,669,348,025$ \\
\hline Korea & $37,072,346,867$ & $(32,411,446,867)$ & Portugal & $7,540,514,460$ & $5,533,672,662$ \\
\hline Chile & $36,596,697,177$ & $(19,297,681,290)$ & Vietnam & $3,017,454,965$ & $4,412,545,035$ \\
\hline Belgium & $36,517,852,369$ & $65,481,706,161$ & Philippines & $(2,228,757,234)$ & $4,097,757,234$ \\
\hline Spain & $27,522,317,936$ & $3,896,969,036$ & El Salvador & $(3,842,946,593)$ & $4,090,366,593$ \\
\hline Uruguay & $25,434,758,633$ & $(23,257,519,110)$ & Peru & $4,180,770,743$ & $4,051,866,236$ \\
\hline Slovak Republic & $25,116,669,516$ & $(21,458,369,437)$ & Spain & $27,522,317,936$ & $3,896,969,036$ \\
\hline Ireland & $23,798,201,953$ & $(12,292,056,159)$ & Malaysia & $10,053,353,967$ & $1,947,402,417$ \\
\hline Saudi Arabia & $21,891,473,839$ & $(5,583,193,839)$ & Turkey & $14,408,185,397$ & $1,640,814,603$ \\
\hline Poland & $21,592,353,931$ & $(6,296,353,931)$ & Argentina & $7,394,266,590$ & $1,276,414,200$ \\
\hline Czech Republic & $20,040,362,931$ & $(14,659,948,033)$ & $\begin{array}{l}\text { Trinidad and } \\
\text { Tobago }\end{array}$ & $(406,723,843)$ & $980,723,843$ \\
\hline Slovenia & $20,018,726,849$ & $(19,200,736,893)$ & Bangladesh & $1,782,778,828$ & $(985,237,649)$ \\
\hline Lithuania & $19,834,583,575$ & $(18,391,501,823)$ & Canada & $44,219,179,180$ & $(4,709,063,328)$ \\
\hline Russia & $16,747,463,093$ & $36,131,012,707$ & Israel & $16,364,508,744$ & $(4,990,808,744)$ \\
\hline Israel & $16,364,508,744$ & $(4,990,808,744)$ & Saudi Arabia & $21,891,473,839$ & $(5,583,193,839)$ \\
\hline Malta & $16,350,744,239$ & $(15,884,179,536)$ & Hungary & $15,412,951,279$ & $(5,784,211,552)$ \\
\hline Hungary & $15,412,951,279$ & $(5,784,211,552)$ & Poland & $21,592,353,931$ & $(6,296,353,931)$ \\
\hline Turkey & $14,408,185,397$ & $1,640,814,603$ & South Africa & $12,332,756,064$ & $(6,443,449,083)$ \\
\hline Brazil & $14,034,005,920$ & $57,504,651,489$ & Romania & $9,210,062,939$ & $(6,653,062,939)$ \\
\hline Bulgaria & $12,782,855,391$ & $(10,195,000,297)$ & Croatia & $10,239,776,987$ & $(8,974,786,024)$ \\
\hline South Africa & $12,332,756,064$ & $(6,443,449,083)$ & United Kingdom & $45,696,196,640$ & $(9,452,398,812)$ \\
\hline Indonesia & $11,559,491,958$ & $6,600,041,773$ & Latvia & $10,954,714,001$ & $(9,452,414,001)$ \\
\hline Latvia & $10,954,714,001$ & $(9,452,414,001)$ & Bulgaria & $12,782,855,391$ & $(10,195,000,297)$ \\
\hline Croatia & $10,239,776,987$ & $(8,974,786,024)$ & Ireland & $23,798,201,953$ & $(12,292,056,159)$ \\
\hline Malaysia & $10,053,353,967$ & $1,947,402,417$ & Czech Republic & $20,040,362,931$ & $(14,659,948,033)$ \\
\hline Romania & $9,210,062,939$ & $(6,653,062,939)$ & Malta & $16,350,744,239$ & $(15,884,179,536)$ \\
\hline Italy & $8,379,461,065$ & $19,623,061,601$ & Lithuania & $19,834,583,575$ & $(18,391,501,823)$ \\
\hline Portugal & $7,540,514,460$ & $5,533,672,662$ & Slovenia & $20,018,726,849$ & $(19,200,736,893)$ \\
\hline Argentina & $7,394,266,590$ & $1,276,414,200$ & Chile & $36,596,697,177$ & $(19,297,681,290)$ \\
\hline India & $6,238,908,416$ & $25,951,091,584$ & Germany & $59,238,448,312$ & $(20,171,679,096)$ \\
\hline Mexico & $4,464,405,583$ & $16,358,892,270$ & Slovak Republic & $25,116,669,516$ & $(21,458,369,437)$ \\
\hline Peru & $4,180,770,743$ & $4,051,866,236$ & Uruguay & $25,434,758,633$ & $(23,257,519,110)$ \\
\hline Vietnam & $3,017,454,965$ & $4,412,545,035$ & Austria & $43,080,037,314$ & $(27,346,111,105)$ \\
\hline
\end{tabular}


Appendix A cont.

\begin{tabular}{|l|c|c|c|c|c|}
\hline Colombia & $2,937,878,918$ & $10,666,821,827$ & Korea & $37,072,346,867$ & $(32,411,446,867)$ \\
\hline Bangladesh & $1,782,778,828$ & $(985,237,649)$ & Netherlands & $46,647,840,133$ & $(32,762,075,278)$ \\
\hline Thailand & $1,051,109,337$ & $6,728,898,492$ & Denmark & $46,126,896,617$ & $(33,021,322,379)$ \\
\hline $\begin{array}{l}\text { Trinidad and } \\
\text { Tobago }\end{array}$ & $(406,723,843)$ & $980,723,843$ & Norway & $41,700,446,744$ & $(34,419,827,018)$ \\
\hline Philippines & $(2,228,757,234)$ & $4,097,757,234$ & Luxembourg & $54,229,716,846$ & $(35,864,212,815)$ \\
\hline Morocco & $(3,564,731,527)$ & $6,086,096,172$ & Estonia & $41,048,740,427$ & $(40,612,653,929)$ \\
\hline El Salvador & $(3,842,946,593)$ & $4,090,366,593$ & Japan & $43,906,638,879$ & $(43,827,557,674)$ \\
\hline Pakistan & $(4,360,578,025)$ & $5,669,348,025$ & Sweden & $50,198,738,419$ & $(47,144,849,022)$ \\
\hline Venezuela & $(9,410,732,050)$ & $14,636,732,050$ & Switzerland & $58,502,735,497$ & $(48,425,610,794)$ \\
\hline Greece & $(17,522,800,305)$ & $18,614,780,944$ & New Zealand & $54,031,593,996$ & $(49,746,484,373)$ \\
\hline Egypt & $(21,001,004,797)$ & $20,518,304,797$ & Finland & $45,127,851,608$ & $(50,885,848,323)$ \\
\hline
\end{tabular}

